\title{
The levels of anxiety, depression and alexithymia in individuals diagnosed with diabetes and the affecting factors
}

\author{
Diyabet tanılı bireylerin anksiyete, depresyon, aleksitimi düzeyleri ve \\ etkileyen faktörler
} Arife Zühal Değirmencioğlu1, Leyla Baysan Arabacı2, Nalan Gordeles Beser ${ }^{3}$
${ }^{1}$ Assis. Prof., Niğde Ömer Halisdemir University Faculty of Medicine, Nigde, Turkey https://orcid.org/0000-0003-4900-1699
2Prof., İzmir Katip Çelebi University Faculty of Health Sciences Department of Psychiatric Nursing, Izmir, Turkey
https://orcid.org/0000-0002-0314-6350
3Assoc. Prof., Niğde Ömer Halisdemir University Niğde Zübeyde Hanım School of Health Department of Psychiatric Nursing, Nigde, Turkey
https://orcid.org/0000-0001-6054-0437

\section{SUMMARY}

Objective: This study aims to determine the levels of anxiety, depression and alexithymia in individuals diagnosed with diabetes and the affecting factors. Method: The study consisted of 208 patients aged 18 and over diagnosed with diabetes that have been receiving relevant treatment for at least 6 months and had no other chronic diseases. The patients had been registered in the internal medicine outpatient department of a training and research hospital for follow-up between January 15 and June 30, 2018 and had agreed to participate in the study. Results: In the study $61.1 \%$ of the patients were females, $57.7 \%$ were between $45-64$ years old and $81.3 \%$ were married. A moderate-level of anxiety and alexithymia as well as a low-level of depression were found in the patients who reported adverse changes in their lives following the diagnosis of diabetes. A statistically significant relationship was found between the levels of anxiety, depression and alexithymia in the patients $(p<0.001)$. Discussion: Patients diagnosed with diabetes should be regularly assessed for psychological distress such as anxiety, depression and alexithymia, as well as physical symptoms. Health professionals, especially nurses should support diabetic patients in developing strategies to cope with and manage these health problems.

Key Words: Anxiety, Alexithymia, Depression, Diabetes

(Turkish J Clinical Psychiatry 2021;24:475-480)

DOI:10.5505/kpd.2021.39259

\section{ÖZET}

Amaç: Diyabet tanısı alan bireylerin, anksiyete, depresyon ve aleksitimi düzeyleri ile bunları etkileyen faktörleri belirlemek amacıyla yapılmıştır. Yöntem: Tanımlayıcı, kesitsel ve ilişki arayıcı nitelikteki araştırma örneklemi evreni bilinmeyen örneklem belirleme yöntemi ile 195 olarak hesaplanmış ve buna göre,15 Ocak-30 Haziran 2018 tarihleri arasında, bir eğitim araştırma hastanesinin iki dahiliye polikliniğine kontrol amacıyla başvuran, araştırmaya katılmayı kabul eden, en az 6 aydır diyabet tanısıyla tedavi olan ve başka kronik bir hastalığı olmayan, 18 yaş üstü 208 diyabet tanılı hastaya ulaşılmıştır. Bulgular: Hastaların \%61.1'inin kadın, \%57.7'sinin 45-64 yaş arasında ve \%81.3'ünün evli olduğu bulunmuştur. Diyabet tanısı sonrası yaşamlarında olumsuz yönde değişiklikler yaşadığını belirten hastalarda orta düzeyde anksiyete ve aleksitimi, düşük düzeyde de depresyon belirtileri tespit edilmiştir. Hastaların anksiyete ve depresyon düzeyleri ile aleksitimi düzeyleri arasında istatistiksel olarak anlamlı bir ilişki olduğu bulunmuştur $(p<0.001)$ Sonuç: Diyabet tanılı hastalar$\mathrm{da}$, fiziksel semptomlar ve bunların yönetimi kadar anksiyete, depresyon, aleksitimi gibi ruhsal sıkıntılar da düzenli olarak değerlendirilmeli ve hastalar bu sorunlarla başetme stratejileri geliştirebilmeleri için sağlık çalışanları özellikle hemşireler tarafından desteklenmelidir.

Anahtar Sözcükler: Diyabet, Anksiyete, Depresyon, Aleksitimi 


\section{INTRODUCTION}

Diabetes mellitus (diabetes) is a systemic, chronic, metabolic disease $(1,2)$. Disability, weakness, and stress in the work and home environment negatively affect the health of diabetic patients, causing furt-her increases in blood glucose levels accelerating tissue and organ damage $(1,2,3)$. Individuals diagnosed with diabetes do not only experience physical problems. Studies report that individuals diagnosed with diabetes also have psychological problems which increase the physical symptoms of diabetes $(4,5,6,8,9)$. A study conducted to determine the levels of anxiety and depression in diabetic patients found that $30.8 \%$ and $51.1 \%$ of the patients obtained scores above the threshold of anxiety and depression subscales, respectively (7). Therefore, it is necessary to assess patients diagnosed with diabetes using a holistic approach. Existing and potential physical, psychological and social problems in patients should be evaluated starting from the onset of the disease with individual care plans and treatment program specific for each patient initiated. Psychosocial problems patients experience can only be determined by interviewing them. However, individuals with chronic illnesses, especially those with diabetes, often cannot identify their feelings because of the physical symptoms they experience. This is explained by the concept of "alexithymia" in the literature (10). Studies report that alexithymic individuals call for help using physical symptoms, because they cannot describe their feelings $(10,11,12,13)$. Studies show that difficulty in understanding and expressing feelings by patients with alexithymia also makes it difficult to manage chronic diseases and increases psycho-social problems. It is important for patients with diabetes to manage the physical symptoms and to cope with the emotions and disability caused by the disease. Therefore, an evaluation of alexithymia and its relation to depression-anxiety level in chronic diseases will guide health professionals in holistic care and treatment of individuals, especially in diabetes where psychosocial variables are known to affect the disease prognosis. This study was conducted to evaluate the presence of alexithymia in adult patients diagnosed with diabetes and its relationship to depression-anxiety level as well as the affecting factors.

\section{METHODS}

The sample of this cross-sectional, correlational and descriptive study consisted of 208 adult patients diagnosed with diabetes. These patients were registered in eight internal medicine outpatient units of a training and research hospital in a province in Central Anatolia region of Turkey between January 15 and June 30, 2018. The study sample size was calculated using the sampling method for an unknown population. Considering possible absentees, the study consisted of 208 patients aged 18 and over diagnosed with diabetes that have been receiving relevant treatment for at least 6 months and had no other chronic diseases. The University's Non-Interventional Clinical Research Ethics Committee approved the study (Decision No. 2017/12-03, dated: November 30, 2017). The hospital where the research was conducted gave permission.

\section{Data were collected using the following four data collection tools.}

Personal Information Form (PIF): This form was consisted of 17 questions to determine the patients' socio-demographic characteristics and the effects of the chronic disease on the patients.

Beck Depression Inventory (BDI): The BDI was developed by Beck et al. (1961), and the Turkish validity and reliability of the scale was developed by Nesrin Hisli Şahin (14). This 21 item self-report scale evaluated the effects of depression on an individual. The reliability coefficient of the scale for this sample was found to be 0.906 .

Beck Anxiety Inventory (BAI): The BAI was developed by Beck et al. (1988), and the Turkish validity and reliability of the scale was developed by Ulusoy et al. (1998) (14). This was a self-assessment scale used to determine the frequency of anxiety symptoms experienced by individuals. The reliability coefficient of the scale for this sample was found to be 0.923 .

Toronto Alexithymia Scale (TAS-20): The TAS-20 was developed by Taylor et al. (1992), and the 
The levels of anxiety, depression and alexithymia in individuals diagnosed with diabetes and the affecting factors

Table 1: Distribution of Anxiety, Depression and Alexithymia Point Averages of Patients

\begin{tabular}{lllll}
\hline & \multicolumn{1}{c}{ X-sd } & Median & Minimum & Maximum \\
\cline { 2 - 5 } Depression & $16.95-10.7$ & 16.00 & 0.00 & 42.00 \\
\hline Anxiety & $35.83-10.7$ & 33.00 & 21.00 & 70.00 \\
\hline Difficulty Identifying Feelings & $16.18-5.2$ & 16.00 & 7.00 & 30.00 \\
\hline Difficulty Describing Feelings & $14.55-3.0$ & 15.00 & 5.00 & 23.00 \\
\hline Externally-Oriented Thinking & $24.55-5.4$ & 25.00 & 8.00 & 36.00 \\
\hline Alexithymia & $55.26-9.2$ & 56.00 & 20.00 & 79.00
\end{tabular}

Turkish validity and reliability of the scale was developed by Güleç et al. (2009) $(11,15)$. The cutoff score of the scale was found to be 61 . High scores on the scale indicate high level of alexithymia. The reliability coefficient of the scale for this sample was found to be 0.679 .

The descriptive statistics, Kruskal Wallis, Mann Whitney $\mathrm{U}$ and Pearson Correlation tests and regression were used in the statistical analysis of the data.

\section{RESULTS}

Among the participants, $61.1 \%$ were females, $57.7 \%$ were between $45-64$ years old and $81.3 \%$ were married. In addition, $55.8 \%$ were living in city centers, and $45.2 \%$ were primary school graduates. Twenty-six percent of the participants were employed and $60.5 \%$ were of a middle-income status. Moreover, $93.3 \%$ were diagnosed with Type II diabetes.

The patients' mean depression, anxiety and alexithymia scores were $16.95 \pm 10.7,35.83 \pm 10.7$, and $55.26 \pm 9.2$ respectively (Table 1 ).

A strong positive relationship was found between the patients' anxiety mean score and the mean scores on the subscales of "difficulty identifying feelings" and "difficulty describing feelings" $(p<0.001)$. In addition, a strong positive relationship was found between the patients' depression mean score and the mean scores on the subscales of "difficulty identifying feelings" and "difficulty describing feelings" $(\mathrm{p}<0.001)$ (Table 2).

Female diabetic patients were found to experience significantly more anxiety symptoms and have a higher level of alexithymia, whereas male diabetic patients were found to experience significantly more depression symptoms. The following patients were found to experience significantly more anxiety and depression symptoms $(\mathrm{p}<0.05)$ : illiterate and divorced patients, housewives, and Type I diabetics, patients who received support from relatives (sibling, mother and father), patients who reported lower job performance, patients who quit their jobs, patients who had financial difficulty, patients who had communication problems with their family, patients who could not fulfill their responsibilities within the family, and patients who had poor mental health and quality of life. When the anxiety and depression level of the patients and the variables compared; the marital status (VIF $=3,025$ ) and disease due to illness (VIF $=1,327)$ was found to be major variables affecting the level of anxiety $(\mathrm{p}<0.05)$ and type of diabetes $(\mathrm{VIF}=1.325)$, who giving the patient care (VIF $=2,894)$, had to quit the job $(\mathrm{VIF}=1,327)(\mathrm{VIF}=1,361)$, and the problem of communicating with his wife $(\mathrm{VIF}=1.361)$

Table 2: The Relationship between Patient's Anxiety Scale, Depression Scale, and Alexithymia Subscale Averages

\begin{tabular}{|c|c|c|c|c|c|c|c|}
\hline & & Anxiety & Depression & Alexithymia & $\begin{array}{l}\text { Difficulty } \\
\text { Identifying } \\
\text { Feelings }\end{array}$ & $\begin{array}{l}\text { Difficulty } \\
\text { Describing } \\
\text { Feelings }\end{array}$ & $\begin{array}{l}\text { Externally- } \\
\text { Oriented } \\
\text { Thinking }\end{array}$ \\
\hline \multirow[t]{3}{*}{ Anxiety } & $\begin{array}{l}\text { Pearson } \\
\text { Correlation }\end{array}$ & & $.543^{* *}$ & $.186^{* *}$ & $.490^{* *}$ & .087 & $-.208^{* *}$ \\
\hline & Sig. (2-tailed) & & .000 & .007 & .000 & .213 & .003 \\
\hline & $\mathrm{N}$ & & 208 & 208 & 208 & 208 & 208 \\
\hline \multirow[t]{3}{*}{ Depression } & $\begin{array}{l}\text { Pearson } \\
\text { Correlation }\end{array}$ & $.543^{* *}$ & & $.188^{* *}$ & $.461^{* *}$ & $.148^{*}$ & $-.215^{* *}$ \\
\hline & Sig. (2-tailed) & .000 & & .007 & .000 & .033 & .002 \\
\hline & $\mathrm{N}$ & 208 & & 208 & 208 & 208 & 208 \\
\hline
\end{tabular}

* Correlation is significant at the 0.05 level (2-tailed).

**. Correlation is significant at the 0.01 level (2-tailed). 
were found to be major variables affecting depression level $(\mathrm{p}<0.05)$

The following patients were found to have higher alexithymia mean scores, but these differences were not statistically significant $(p>0.05)$ : illiterate patients, patients working in the private sector, single patients, patients diagnosed with Type I diabetes, patients who received support from their spouses, patients who reported lower job performance, patients who quit their jobs, patients who had financial difficulties, patients who had communication problems with their family, patients who could not fulfill their responsibilities within the family, and patients who had poor mental health and quality of life.

however, these point differences were found to be statistically significant only in patients who had a partial economic distress, who had difficulty communicating with their spouses and children, and partially fulfilled their responsibilities in the family $(p>0.05)$. In the regression analysis; profession $(\mathrm{VIF}=2,853)$, where he lived (VIF $=1,191)$, family type (VIF $=1,180)$ and fulfill the responsibility in the family status (VIF $=1.599$ ) was found to be major variables affecting alexithymia $(\mathrm{p}<0.05)$.

\section{DISCUSSION}

According the results; the participants diagnosed with diabetes had low depression mean score, but moderate anxiety mean score. Their alexithymia mean score was slightly below the cut-off point (61), which indicated a moderate level of alexithymia. Similarly, Chatziet al. (2009) conducted a study on patients with and without diabetes, and found that diabetic patients' depression mean score $(8.5 \pm 11.9)$ was below the average, their alexithymia total score $(48.3 \pm 11.9)$ was slightly below the cut-off score (6). According to this finding, depression symptoms are not common in diabetic patients, but they may have alexithymia characteristics. However, there are study results that are in conflict with these findings. Some studies report that individuals diagnosed with diabetes have diabetes-induced psychological distress, anxiety, alexithymia, and depression symptoms $(16,17)$.
The presence of different results in different studies may be due to individual characteristics of patients and cultural factors in different populations. Although the findings from various studies are different, all study results show that diabetic patients have moderate anxiety and alexithymia symptoms, and low levels of depression. In support of this idea, Nichols and Brown (2003) found the prevalence of depression to be $11.2 \%$ in diabetic patients (17). Gülseren et al. (2002) determined that the rate of having depression and anxiety was higher in Type I diabetic patients than Type II patients (5). Zenteno and Cardiel (2002) found that $33 \%$ of individuals with Type II diabetes had depression (18). Avc1 and Kelleci (2016) reported that the alexithymia mean score of patients with Type II diabetes was $56.92 \pm 9.05$ (13).

A strong positive relationship was found between the diabetic patients' BAI and BDI mean scores and mean scores on TAS-20 total scale and the subscales of "difficulty identifying feelings (TAS-1)" and "difficulty describing feelings (TAS$2)$ " $(\mathrm{p}<0.001)$. Accordingly, as the levels of anxiety and depression increased, the difficulty in identifying and describing feelings increased and the ability of externally-oriented thinking decreased. Studies also report that as the anxiety and depression mean scores increase, the mean scores on alexithymia total scale and two subscales (difficulty identifying feelings and difficulty describing feelings) increase, whereas the mean score on alexithymia scale (externally-oriented thinking) decreases $(6,15)$.

Avcı and Kelleci (2016) found a significant association between alexithymia, anxiety and depression (13). Topsever el al (2006) state that diabetes is associated with alexithymia and alexithymic diabetic individuals lose their ability to regulate body signals and feelings which makes them prone to perceive stress (19). Alexithymic individuals have difficulty in identifying and describing their feelings and are less able to perceive and cope with stress, consequently they are also known to have increased levels of alexithymia in case of a disease (20). Accordingly, there may be a vicious cycle between anxiety, diabetes and alexithymia. If a diabetic patient fails to cope with stress, they perceive a high level of stress causing anxiety, have difficulty in identifying, distinguishing and describing their 
feelings, and therefore cannot regulate blood glucose levels. As a result, the functionality of the individual with an increased blood glucose level is impaired and they suffer from loss of power, causing the individual to have more stress resulting in a vicious cycle.

Female diabetic patients were found to experience significantly more anxiety symptoms and have higher levels of alexithymia, whereas male diabetic patients were found to experience significantly more depression symptoms. However, other studies in this area indicate that female diabetic patients are more likely to experience both anxiety and depression symptoms. Sönmez and Kasım (2013) found that women with diabetes had higher anxiety and depression mean scores (21). Gülseren et al (2001) determined that the incidence of anxiety and depression was higher in women with diabetes (21). Similar to the present study, Topsever et al (2006) reported that female diabetic patients had significantly higher alexithymia mean scores(19).

On the other hand, diabetic patients who are illiterate, housewives, divorced, Type I diabetics and those who received support from relatives were found to experience significantly more anxiety and depression symptoms $(\mathrm{p}<0.05)$. Additionally, diabetic patients who reported lower job performance, quit their jobs, experienced financial difficulty or communication problems were found to experience significantly more anxiety and depression symptoms $(\mathrm{p}<0.05)$, as well as patients who could not fulfill family responsibilities and had poor mental health and quality of life. In regression analysis, it has been found that for the anxiety of the marital status due to the disease, the type of diabetes, who takes care of the patient, the state of cessation and the problem of communication with his wife are the major variable for depression. This result indicates that the loss of spouse and job, inability to fulfill responsibilities and economic difficulties during the disease process cause diabetic patients to experience more stress, more inability to cope with problems, more anxiety and depression due desperation and other disease-induced problems. Some studies also report that the disability and possible loss in work and domestic life adversely affects the quality of life and mental health in patients with diabetes and other chronic diseases $(7,8,12)$.
Similarly, Adakan et al (2017) found a higher anxiety mean score in patients with low income level and a higher depression mean score in patients with low education levels (1). Sönmez et al. (2013) conducted a study on diabetic patients, and reported that as the education level of patients increased their depression scores decreased (21).

In addition, diabetic patients who were illiterate, working in private sector, single, Type I diabetic, receiving support from their spouses, and who reported lower job performance were found to have higher alexithymia mean scores. Additionally, diabetic patients who quit their jobs, had financial difficulties, communication problems or could not fulfill responsibilities within their family, who had poor mental health and quality of life were found to have higher alexithymia mean scores, but these differences were not statistically significant $(p>0.05)$. In the regression analysis; it was found that the profession, the place where he lived, the type of family and the fulfillment of responsibility within the family were the major variables affecting alexithymia. Studies emphasize the importance of cognitive functions in alexithymia, which is defined as emotional blindness. They also stated that psychological distress due to low levels of education, lack of social support, disability and diseaseinduced negative changes in individuals' lives negatively affects cognitive functions. Therefore, it is more likely that alexithymia symptoms are observed in illiterate patients, single patients who try to cope alone with disease-induced problems, and patients who lose their financial and moral support or experience economic losses due to the disease. Similarly, Stingl et al. (2018) compared diabetic patients with normal populations, and found a higher level of alexithymia in patients with diabetes (22). In addition, Yiğitbaş (2017) reported that as the level of general, physical, mental and emotional health perception decreased in the elderly, their alexithymia mean scores increased (23). Similarly, Mattila et al. (2006) found that individuals with low level of general health perception had a higher alexithymia mean score (20).

\section{CONCLUSION}

As a result of study; statistically significant relation- 
ship was found between the levels of anxiety, depression and alexithymia in diabetic patients. Diabetic patients who were female, illiterate, Type I diabetics, who reported lower job performance or quit their jobs were found to have higher anxiety, depression and alexithymia symptoms. Additionally, diabetic patients who had financial difficulty, communication problems or could not fulfill responsibilities with family members, had poor mental health and quality of life were found to have higher anxiety, depression and alexithymia symptoms.
Correspondence address: Assis. Prof. Arife Zuhal Degirmencioglu, Niğde Ömer Halisdemir University Faculty of Medicine, Nigde, Turkey_nalanbeser@hotmail.com

\section{REFERENCES}

1. Adakan F, Vural R, Sahintürk Y, Boylubay SM, Yılmaz U, Kulaksızoğlu B, Yeşil B, Ünal A. Diyabetik ve non-diyabetik kişilerde sosyo-demografik ve klinik faktörlerin depresyon ve anksiyete düzeyleri ile ilişkisi. Konuralp Tip Dergisi 2017; 9(2):96-105. DOI: $10.18521 / \mathrm{ktd} .289610$

2. Uygur MM, Gogas Yavuz D. Diyabet tanisı ve sinıflandırılması. Turkiye Klinikleri J NutrDiet-Special Topics 2017;3(3):120-9.

3. Eren İ, Erdi Ö, Özcankaya R. Tip 2 diyabetik hastalarda kan şekeri ve psikiyatrik bozuklukların ilişkisi. Türk Psikiyatri Derg 2003; 14:184-191

4. Gülseren L, Hekimsoy Z, Gülseren F, Bodur Z, Kültür S. Diyabetes mellituslu hastalarda depresyon, anksiyete, yeti yitimi ve yaşam kalitesi. Türk Psikiyatri Derg 2001; 12:89-98.

5. Gülseren Ş, Böncü B, Aydemir Ö, Kültür S. Tip I ve Tip II diabetes mellituslu hastalarda anksiyete ve depresyon. 3P Dergisi 2002; 10:59-64.

6. Chatz L, Bitsios P, Solidaki E, Christou I, Kyrlaki E, Sfakianaki M, Kogevinas,M, Kefalogiannis N, Pappas A. Type 1 diabetes is associated with alexithymia in nondepressed, nonmentally ill diabetic patients: A case-control study. Journal of Psychosomatic Research 2009; 67.307-313. https://doi.org/10.1016/j.jpsychores.2009.04.011

7. Bahar A, Sertbas G, Sönmez A. Diyabetes mellituslu hastaların depresyon ve anksiyete düzeylerinin belirlenmesi. Anatolian Journal of Psychiatry 2006; 7:18-26

8. Kızıltaş Ö, Arslan İ, Tekin O, Fidancı İ, Kızıltaş B, Kuzulu A, Çelik M, Çiğdem E. Tip 2 Diyabet Hastalarında psikolojik belirtilerin incelenmesi. Konuralp Tip Dergisi 2016; 8(3) 187194.https://doi.org/10.18521/ktd.284654

9. Buzlu S. Diyabetin psikososyal yönü. Florence Nightingale Hemşirelik Dergisi 2009; 12(45).

10. Ira M, Lesser E.M. A review of the alexithymia concept. Psychosom Med. 1981; 43:531-543.

11. Taylor GJ, Bagby RM, Parker J D A. The revised Toronto alexithymia scale: some reliability, validity, and normative data. Psychother Psychosom 1992; 57:34-41.DOI: 10.1159/000288571

12. Asi Karakaş S, Yılmaz Karabulutlu E, Çevik Akyıl R, Erdem N, Bahçecioğlu Turan G. Hipertansiyon ve astım hastalarında aleksitimi ve sosyal desteğin incelenmesi. Psikiyatri Hemşireliği Dergisi .2016; 7(2):68-74.Doi: 10.5505/phd.2016.40085.
13. Avcı M, Kelleci M. Alexithymia in patients with type 2 diabetes mellitus: the role of anxiety, depression, and glycemic control. Patient Preference and Adherence . 2016;12711277.doi.org/10.2147\%2FPPA.S110903

14. Aydemir Ö, Köroğlu E. Psikiyatride kullanılan klinik ölçekler. Hekimler Yayın Birliği. 2009;93-335

15. Güleç H, Köse S, Güleç MY, Çıtak S, Evren C, Borckardt J, Sayar S. Reliability and factorial validity of theTurkish version of the 20-Item Toronto Alexithymia Scale (TAS-20). Bulletin of Clinical Psychopharmacology 2009; 19:214-220

16. Motan I, Gençöz T. Aleksitimi boyutlarının depresyon ve anksiyete belirtileri ile ilişkileri. Türk Psikiyatri Dergisi. 2007;18(4):333-343

17. Nichols GA, Brown JB. Unadjusted and adjusted prevalence of diagnosed depression in Type 2 diabetes. DiabetesCare 2003; 26:744-749. DOI:10.2337/diacare.26.3.744

18. Zenteno J.FT, Cardiel M.H. Risk factors associated with depression in patients with Type 2 diabetes mellitus. Arch Med Res. 2002; 33:53-60.

19. Topsever P, Filiz TM, Salman S., Sengül A, Saraç E, Topallı $\mathrm{R}$, Gorpelioğlu S, Yılmaz T. Alexithymia in diabetes mellitus. Scottish Medical Journal. 51 (3): 15-20. https://doi.org/10.1258\%2FRSMSMJ.51.3.15

20. Mattila A K, Salminen J K, Nummi T, Joukamaa M. Age is strongly associated with alexithymia in the general population. $\mathrm{J}$ Psychosom Res. 2006; 629-35. http://dx.doi.org/10.1016/j.jpsychores.2006.04.013

21. Sönmez B, Kasım İ. Diabetes mellitus'lu hastaların anksiyete, depresyon durumları ve yaşam kalitesi düzeyleri. Türk Aile Hek Derg. 2013;(3):119-124.

22. Stingl M, Naoundorf K, Felde, L, Hanewal B. Alexithmia in type I and type II diabetes. Intervention in Obesity\&Diabetes 2018; 1(3). 3DOI:10.31031/IOD.2018.01.000512.

23. Yiğitbaş Ç. Altmışbeş yaş üstü kadınlarda aleksitimi. Fırat Med J. 2017;22 (4): 181-186 